\title{
David Oliver: Radical pragmatism and medical leadership
}

\author{
David Oliver consultant in geriatrics and acute general medicine
}

Berkshire

My recent column on the paucity of doctors as NHS hospital chief executives brought an interesting postbag, sparking more reflection on my part. ${ }^{1}$

Clinically active doctors can often assume management, educational, and leadership roles that stop short of full time organisational executive. Perhaps the lack of doctor chief executives isn't a big deal if we're influential in other ways. ${ }^{2}$

One of my Twitter respondents, Jill Aylott, argued that medical leadership is indivisible from practice because delivering continuous quality improvement for patients was what counted, requiring concrete actions. ${ }^{3}$ The implication was that a serious focus on clinical quality and safety requires more doctors and other clinicians in charge and fewer career managers. I'm not sure that career managers are less committed to quality than clinicians, but I understand that deep training and experience in the core business of patient care counts. In my original column I cited Amanda Goodall's findings that good organisational and team leaders, in sectors including healthcare, are often best drawn from credible technical experts. ${ }^{4-6}$

I'm reminded of an essay by Richard Bohmer, a doctor and improvement expert, on "The Hard Work of Health Care Transformation."7 He argues that most meaningful improvement in patient care and sustained change sit at a local level in small and medium sized, multidisciplinary clinical teams. The wider organisation exists to ensure the right culture, incentives, investment in managerial and educational support, and data for quality improvement.

Bohmer also states persuasively that quality improvement will never have the perfect workforce or baseline data; the right resources, equipment, or local conditions; or a lack of competing priorities. But this shouldn't justify procrastination. Any context for change is imperfect: in fact, a poor local context is often the impetus.

\section{Constraints and accountabilities}

Another correspondent on Twitter, Dominic Harrison, wrote to me of "prophets" and "kings." ${ }^{8}$ Doctors who want to campaign and criticise (prophets) feel constrained in executive (king) roles that don't readily enable them to speak truth to power, or to the people, but rather come with corporate and regulatory accountabilities. Such doctors, he argued, must embrace "radical pragmatism"- -accepting the constraints and accountabilities and simply getting on with organisational leadership rather than lobbying to influence and change the context.

Many doctors would, I suspect, be uncomfortable embracing radical corporate pragmatism, accepting political and regulatory strictures, focusing solely on how much the organisation is doing to simply maintain performance, and ignoring bad news or challenging the realpolitik. After all, you can solve problems only if you identify and name them.

So, what's the solution for doctors who want to deliver change? In the current policy context of the NHS I just don't believe that its only business is continuous quality improvement, any more than when running a prison or a state school in times of austerity, workforce shortages, and heavy handed central regulation.

I'd suggest that, alongside a focus on quality and how to deliver it, we need to focus on morale, skills, workload, and retention. But much of senior public sector management is currently about struggling to maintain performance levels or to stop decline while dealing with funding shortfalls, crumbling estates, staffing gaps, and complex regulatory and political accountabilities.

In such roles, the real technical experts who understand the business and have the right skill set may not be doctors but career managers all along. They don't have to face the cognitive dissonance between their clinical training, with a traditional focus on the patients and families in front of them and an allegiance to their profession, and a more corporate and politicised set of accountabilities and a wider systems approach. Perhaps the best we can do is encourage, develop, and support doctors who want to tackle these jobs, accepting that medical leadership comes in many guises and not just in the office of chief executive or medical director. 
1 Oliver D. David Oliver: Why aren't more doctors NHS chief executives?BMJ 2019;365:11627. 10.1136/bmj.11627 30967376

2 Thornton J. "Doctors need to step up" - why are there still so few medical chief executives in the NHS?BMJ 2019;365:14341.

3 Aylott J. @drjaylott1: If career managers are more likely to become CEOs in NHS but doctors are more likely to be more successful CEOs, then what is the solution? [and subsequent tweets]. Twitter 2019 Apr 14. https://twitter.com///web/status/ 1117526792468930562

4 Cass Business School. Why great doctors make great leaders-Dr Amanda Goodall. http://selskaberne.dk/sites/selskaberne.dk/files/media/document/Why\%20great\% 20doctors\%20make\%20great\%20leaders.pdf.

5 Stoller JK, Goodall A, Baker A. Why the best hospitals are managed by doctors. Harvard Bus Rev 2016 Dec 16. https://hbr.org/2016/12/why-the-best-hospitals-are-managed-bydoctors.
6 Goodall A. Why technical experts make great leaders. Harvard Bus Rev 2018 Apr 24. https://hbr.org/ideacast/2018/04/why-technical-experts-make-great-leaders.html.

7 Bohmer RMJ. The hard work of health care transformation. N Engl J Med 2016;375:709-11. 10.1056/NEJMp1606458. 27557297

8 Harrison D. @BWDDPH: At some point in their careers leaders need to decide whether they are "A Prophet or a King." Twitter 2019 Apr 30. https://twitter.com/BWDDPH/status/ 1123325264954560512.

Published by the BMJ Publishing Group Limited. For permission to use (where not already granted under a licence) please go to http://group.bmj.com/group/rights-licensing/ permissions 